\title{
Border Structures in Arthurian Manuscript BNF, fr. 95 as an Expression of the Artist's mente propria*
}

\author{
Keywords: manuscript painting, marginalia, borders, Lancelot-Graal Cycle
}

DOI: 10.4312/ars.8.2.59-71

\section{Introduction}

Referring to Bernard of Clairvaux's famous letter in which he denounced the ornamented art of his time, Lilian M. C. Randall lists three characteristics of motifs typical for later Gothic marginalia: as ornaments they are too extravagant, they have distractive influence, and this is all the more problematic since they have "strong appeal [...] even to a 'reluctant' observer" (Randall, 1966, 3). Shortly afterwards, Randall cites the tract Pictor in Carmine, presumably authored by Adam of Dore, where the Cistercian says that the introduction of the denounced motifs into religious art was a consequence of the "criminal presumption of painters" (quoted in Randall, 1966, 5). ${ }^{1}$ At least in their early stages then, these motifs were not only created manu propria, but envisaged as artistically productive (be it in practical terms, because of their decorative usefulness, or meaningful terms, because of their symbolic potentiality) mente propria by the practising artists. ${ }^{2}$

* The Slovene version of this article is available on: http://revije.ff.uni-lj.si/arshumanitas. / Slovenska različica članka je dosegljiva na: http://revije.ff.uni-lj.si/arshumanitas.

1 Bernard of Clairvaux was a man of the twelfth century and Pictor in Carmine dates to the early thirteenth century. The thirteenth century was, however, a time of increasing tolerance towards the kind of motifs Bernard and his contemporaries so forcefully condemned. This went hand in hand with the loosening of moral standards of the clergy which gave rise to many satirical literary works. Literature was also used to mock royal power and to sketch - in a moralizing, but still very amusing manner - virtues and vices of different social classes (the latter was typical for fabliaux in which motifs from epics, romances and contemporary life were used as well); exempla enriched the thirteenth-century literary corpus with moralizing anecdotes from the Scriptures, fables, beast epics, and daily events. All of these provided visual artists with new subjects of marginal satire and from the middle of the thirteenth century onwards manuscript margins became increasingly populated with this sort of ornamentation (Randall, 1966, 5-8).

2 The decorative programs were dependent on the workshop tradition, the taste of the patron, but mainly on the illuminator, who was "in charge of designing the over-all production" (Randall, 1966, 19). Randall points out that even when the same hand was responsible for both the main miniatures and the marginalia, there may be a stylistic difference between the two: the margins provided an opportunity "for more spontaneous individualistic expression" (Ibid., 20). For a distinction between marginal images that are formed of "standard stuff" (and may therefore be seen as merely decorative motifs), and use that is particular to a text of an individual manuscript (and may as such be understood as commenting on the text or other images on the same page/in the same quire), see Huot, 1993, 274ff., and with special regard to BNF, fr. 95, Moore Hunt, 2007, 79-110. 
Bernard and similar minded individuals of his time were, of course, speaking of profane artistic elements intruding into sacred spaces, but the three characteristics are valid also if we are thinking of readers of profane (e.g. literary) texts in (vernacular) manuscripts -more accurately, of their response to what they had read and seen, of the way their reception of the given texts was influenced by the presence of those kinds of motifs. ${ }^{3}$ It is exactly the power of these "inappropriate" motifs to shape the viewer's response that concerned critics of their use in sacred spaces; this means that even if the context in which they appeared changed from religious to profane and their presence was no longer problematic in terms of being (in)appropriate for the given context, they nevertheless retained their power to shape the reader's reception of, for example, a vernacular literary text in a manuscript adorned with this kind of marginalia.

However, before considering iconographical implications of the motifs and scenes depicted in the margins, it is necessary, I believe, to describe and systemize the formal characteristics of the marginalia. ${ }^{4}$ In this paper I wish, firstly, to present the ways the borders shape and affect the mise-en-page and, secondly, to show how compositions are used as elements that connect borders among themselves and sometimes with other marginal figures or elements of the layout. Let me stress again thathere I am only referring to formal connections, not iconographical ones. ${ }^{5}$

\section{Borders as formative elements of the mise-en-page in BNF, ms. fr. 95}

BNF, ms. fr. 95 was made in Thérouanne ca. 1290 (Stones, 2013a, 70). In its present form it is comprised of three Arthurian texts belonging to the Lancelot-Graal or the Vulgate Cycle (Estoire del saint Graal, Merlin, Suite vulgate) and two non-Arthurian texts (Le Roman des sept sages, Pénitence Adam), which were produced by the same team but not necessarily intended to be included in the same codex (Stones, 1996, 204). ${ }^{6}$

3 The third characteristic, the ability to grab the audience's attention, was looked upon favourably by Bernard as well as by thirteenth and fourteenth-century Franciscan and Dominican preachers who were using exempla extensively in their sermons (Randall, 1966, 7, 8).

4 Also Randall was aware of the importance of a formal analysis of the margins. She corrected those that viewed marginal motifs as being apparently unconnected with their immediate context by stating that "the distribution was not always as unsystematic as it appears" and that schemes of the mise-en-page or sections of manuscripts, even if they were flexible and subjected to change, need to be taken into consideration (Randall, 1966, 12).

5 This is an introductory presentation of the subject. In preparation are two further articles on margins in BNF, fr. 95, one dealing with detailed analysis of compositional patterns of the borders, and the other with iconographical questions about the imagery on them.

6 For other information concerning the codex (the measures, its provenance, quire structure, list of motifs, stylistic analysis and further literature) see Loomis and Loomis, 1938, 95-97, Stones, 
There are two types of borders present in BNF, ms. fr. 95. The first type, to which I refer as type $\mathrm{A}$, embraces the text in such a way that the vertical border runs down along the outer (i.e., the left) side of the left column and both horizontal borders (at the top and at the bottom of the page) extend from the left corners across the breadth of the textual space and terminate on the outer (i.e., the right) side of the right column. In the case of the second type - type B - the vertical lines run down along the inner side of the right column, which gives the impression that the writing space is split in two by this internal border. ${ }^{8}$ But the vertical lines are not really positioned between the columns, that is, they are not exactly in the middle: they are "touching" the words of the right column in the same way they touch the words of the left column in the case of the borders of type A, which necessarily means that the vertical line in type B is nearer to the right column.

The decision as to which type of border to use was probably made with regard to where the miniature was (to be placed). Type A is used when the miniature appears in the left column, and type B is used when it appears in the right one. In that way the vertical borders are used to anchor the miniature in its position so it is not left floating around.

Type A is used sixty-two times in the whole manuscript, and type B sixty-five times. This makes one think the layout was perhaps planned in such a way in order to avoid monotony. Of course, a more definite answer about the positioning of miniatures will need to be made with regard to their place in the text. It would be interesting to know whether the planner (or the artist) had some elbow room at his disposal and could to a degree adjust the positioning of miniatures to achieve variety in the layout. ${ }^{9}$ In the Merlin and Suite Vulgate sections of the manuscript many historiated initials are employed "instead" of large miniatures, which is another possible method of dynamizing the appearance of the page. The decorative borders springing from historiated initials are not as extensive as the ones springing from the miniatures: ${ }^{10}$

1970-71 (the pp. where fr. 95 is mentioned are listed in footnote 11 of Stones 1996; of particular interest is Chapter 4, where she discusses stylistic and iconographical features of Thérouanne illumination in the last two decades of the 13th century, while presenting arguments for the dating of mss. in this group; a catalogue entry is on p. 429), Stones 1996, esp. 204-206, Stones, 2013b, 550-557 and 572-575. For a comparative study of the mise-en-page in Arthurian manuscripts, see Stones, 2003.

7 The manuscript is fully digitised and can be consulted at: http://gallica.bnf.fr/ark:/12148/ btv1b6000108b.

8 Stones $(1970-71,170)$ mentions that the borders of manuscripts made in Thérouanne ca. 1280-1300 "frequently form $[. .$.$] a symmetrical arrangement in the centre of the page."$

9 I plan to write about this in the future.

10 One exception to this is the large historiated initial of the opening page to Estoire del saint Graal, where the borders are different than everywhere else in the manuscript. Roughly, they could be seen as the ones forming type A (I count them here). 
they never frame both columns; horizontally they are normally limited to the breadth of the column in which the initial appears, and when they are vertical, they never run along the whole height of the column, and sometimes there is no border at all. ${ }^{11}$

\section{Connecting vertical and horizontal borders: forms and compositions used (an overview)}

\section{Type A}

Type A can be additionally divided into several sub-types if we consider the ways in which horizontal borders are attached to the vertical one. In this paper I will not be giving a thorough examination of all the folios, but will limit myself to a few examples that illustrate the artist's different modelling of the borders, which depends on the type of scenes depicted on them. This means that I will not be commenting on the borders that have no figural scenes or compositions.

The figures present on the borders of type A are normally hybrid musicians riding towards the outer limit of the page, and in many cases some sort of contact is established between them and other figures in the margins, which is the minimum element needed for us to be able to talk of a scene. For example, a hooded centaurmusician playing a cithara is turning his eyes back to the group playing bowls or perhaps even diagonally down to the margin below the right column, where the scene of Phyllis riding Aristotle is depicted (61v); or, in a more complex marginal interplay, a centaur-musician playing bagpipes makes no direct contact with other figures, though there are many indirect indications of possible connections: a twofaced trumpeter in the top right terminal turns one of his faces to the left; the stag head of the mummer below the right column is turned diagonally upwards and thus looks through the miniature towards the centaur bagpiper, and the human head (looking out of the trunk which is the body of this stag's head) is in eye contact with a bagpiper walking along the bottom border, who is looking back towards this creature; in this way, contact is established between both figures playing bagpipes on this folio (f. 261r, Figure 1).

11 This does not mean that the columns on these pages have no borders at all. Rather, they are of a different type that is present on all folios that have no miniature or HI, but only small, three-line-high initials at the beginnings of paragraphs. 


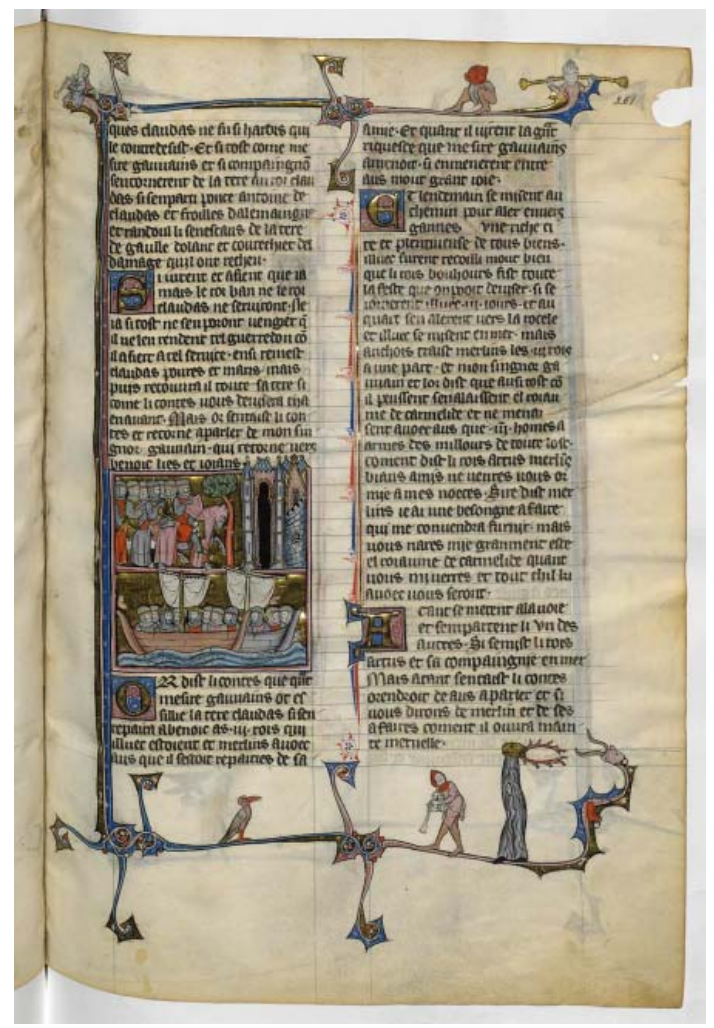

Figure 1: Paris, BNF, ms. fr. 95, f. 261r, Logical contact between marginal figures.

A different case is presented by those where the horizontal and vertical borders are connected through a composite figural motif comprised from at least two figures which are usually involved in some sort of a fight. ${ }^{12}$ The artist treated these scenes in two different manners: he either put a tendril or gold background behind the fighting pair, or he did not. In the latter instances there is no physical but only logical contact between the terminals of the vertical and horizontal borders. This means that in these instances the vertical and horizontal lines do not meet. It seems that the background is preserved when the physical contact between the figures means bodily contact rather than contact between weapons: a headless naked man is bitten in the backside by a dragon (4v), a kiss between a male and a female hybrid (30r, Figure 2), a centaur-soldier turns back to hold an attacking lion's mouth with his left hand and to plunge his sword into the animal with his right hand (86v). A special composition is used whenever the miniature is on top or in the bottom of the column. It is always formed of two figures advancing towards each other and depicted in the moment just before their clash: centaur-youths ride against

12 Mostly this happens in the top left corner. 
each other with raised swords in their right hands and bucklers in their left (33v); male and female hybrids blowing trumpets and ringing bells $(52 \mathrm{v})$; two young men are starting a fight over a game board (the composition is variated a bit by the presence of the board as the third element and by the fact that the men are in physical contact; nevertheless, an effect of two figures coming together from two sides is imparted; 261v).

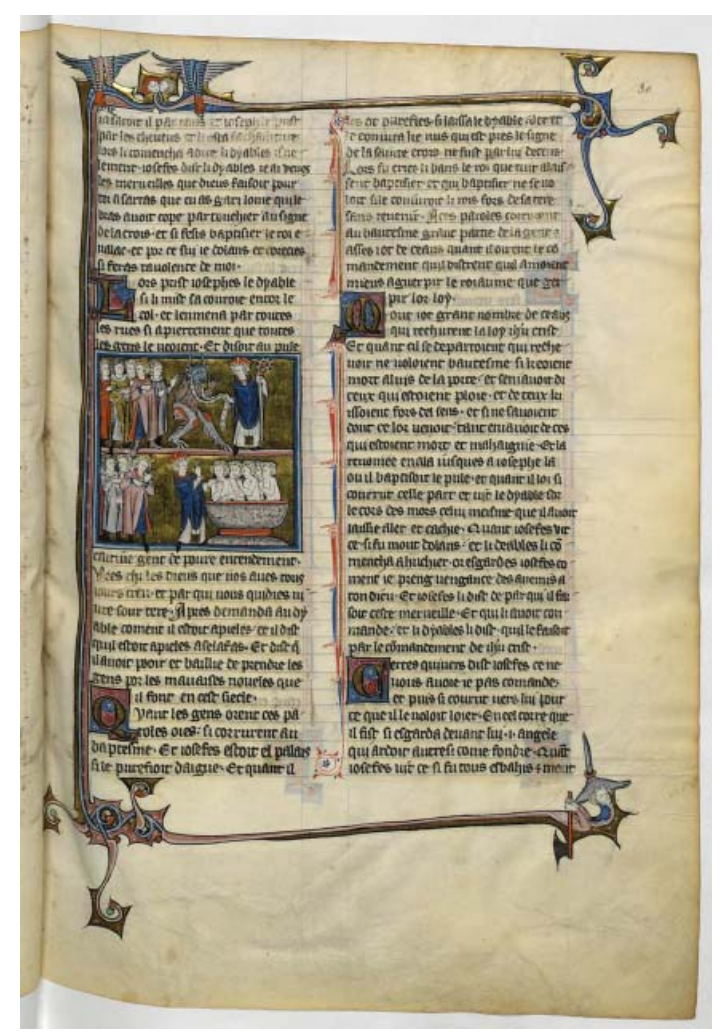

Figure 2: Paris, BNF, ms. fr. 95, f. 30r, Physical contact between marginal figures.

As mentioned, in some instances vertical and horizontal lines do not actually come together. This is similar to the just described composition above or below a miniature, where a fight is more or less already taking place but the opponents have not clashed just yet: a centaur riding to the left is turning its body back to point its sword against a kneeling naked man who is wielding a club over his head (13v); below the left column, a woman on a horseback with a distaff as her weapon strikes towards a soldier riding from the right (the soldier is not armed and is raising his right hand as in an attempt to stop her) (226r). 


\section{Type B}

The vertical and horizontal borders of type B form connections approximately in the middle of the page, above and below both of the columns, but slightly moved towards the right column, as mentioned before. The points of contact between the vertical and horizontal borders are marked by different types of tendril intertwinement, which are uninhabited or inhabited, or by a central figural composition; a special form is used when a miniature appears on top of the right column.

\section{Top border}

The vast majority of top borders have uninhabited intertwinement in the middle; other possibilities are inhabited intertwinements, central figural compositions and figural compositions directly above the miniature. In this paper I deal only with the latter two, similarly as I did with regard to type A.

Almost always vertically, horizontally, or diagonally placed involute tendrils emerge from the top of the intertwinement, usually in mirror position; when vertical, they are sometimes intertwined on top, thus forming a closed space which may be inhabited (e.g. ff. 159v, 186v). When they are placed further apart from each other, they are often used as brackets in which a figural scene is encapsulated: e.g. hybrid-soldiers with raised swords and bucklers are turning outwards and are embraced by vertical involute tendrils; terminals consist of hybrid-youths with bows aiming at the hybridsoldiers (f. 32r, Figure 3). As for the terminals, they are of three types: figural, as in $\mathrm{f}$. $32 \mathrm{r}$, vegetal and pinwheel-shaped; usually the same form is used for terminals on both sides. In one instance among the folios with central figural composition, asymmetrical terminals were employed. On f. 55r a fight is depicted in which the fighting parties are not touching (yet) or are touching only with their weapons: two dragons emerge from the vertical border, and approaching from the left and right are youths with swords and buckler; the one on the left has plunged his sword into a dragon's mouth, the one on the right is wielding it over his head. The left terminal consists of an involute tendril with another vertical extender of the same kind; the right one is of the pinwheel-type.

Pinwheel terminals were employed most in folios with a central figural composition. In these folios no involute tendrils were used as brackets - this means that they are limited to folios where vegetal and figural terminals were used - and therefore it is possible that pinwheel terminals were seen as encapsulating the scene enough and therefore it would have been superfluous to use additional "brackets". In all of these cases one or both terminal(s) lack horizontal extender(s), the latter being true for one folio: a frontally seated hooded man, naked from the waist down, is sitting with his legs stretched out and thus revealing his genitalia; from the horizontal tendril a dragon appears on each side, biting the man's legs 
below his knees, while the man is holding the dragons' necks. The scene is encapsulated by pinwheel terminals consisting only of a vertical ascender and descender (f. 215v). A more dynamic fighting scene is composed of two hybrid-soldiers emerging from the vertical tendril, turned back at each other in a fight; they are holding each other by the head with their left hands, and wielding their swords in their right hands; winged dragons appear from horizontal tendrils, biting the hybrids rear. The left terminal lacks the horizontal extender, while the right one is "complete", consisting of horizontal and both vertical extenders (f. 100r).

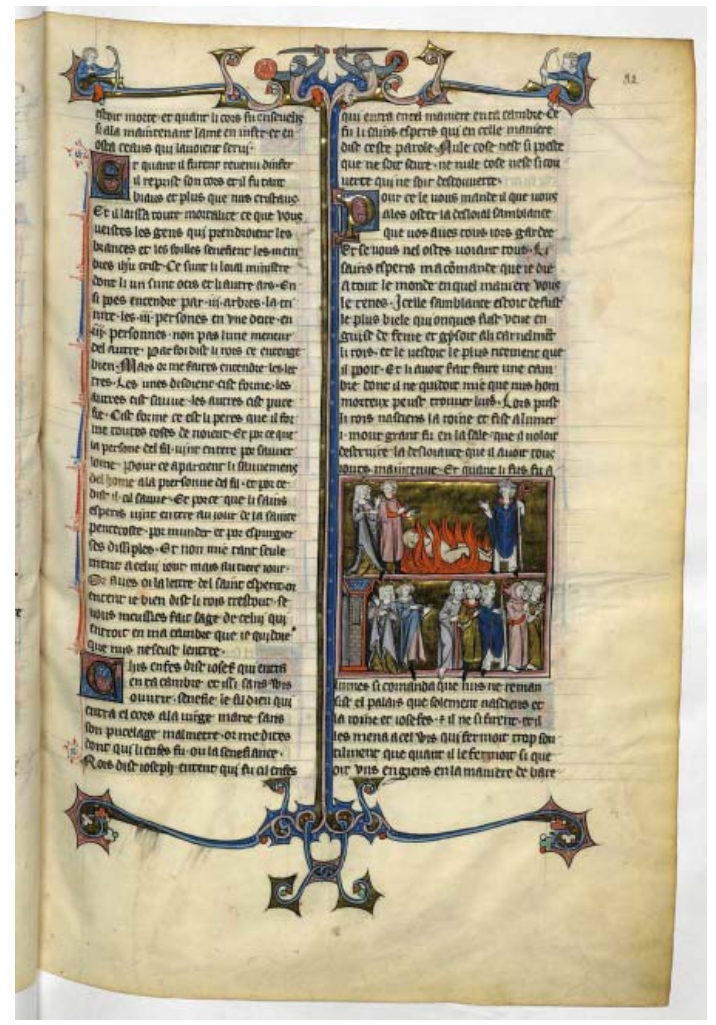

Figure 3: Paris, BNF, ms. fr. 95, f. 32r, A figural scene in brackets.

When the miniature was placed on top of the right column, the same pattern was used as in similar cases in type A: two figures are coming towards one another from different sides. These pages never have figural terminals and neither are the terminals symmetrical. For example, on f. 326r, a winged dragon on the left is facing a young man on the right, wielding a falchion behind his back in order to hit the creature. This example is unique: not only are the terminals not symmetrical, there is no right terminal at all; the left one is formed of an involute tendril. 


\section{Bottom border}

The uninhabited intertwinement was even more widely used in the bottom border than in the top, taking up more than two thirds of the folios: only four folios have a central figural composition. ${ }^{13}$ This is bracketed either by involute tendrils or pinwheel terminals. For the former, see f. 159v, where two pairs of winged dragons are biting each other in the rear; the scene is encapsulated by involute tendrils above the bottom border and the breadth of the space it takes is defined by the tendrils below the border. For the latter, see f. $343 \mathrm{v}$, where the vertical tendril ends in two symmetrically positioned apes in bishop's robes with sheet music in their hands, turned outwards; the horizontal tendrils end in dragons whose heads are placed behind the "bishops" but there is no biting.

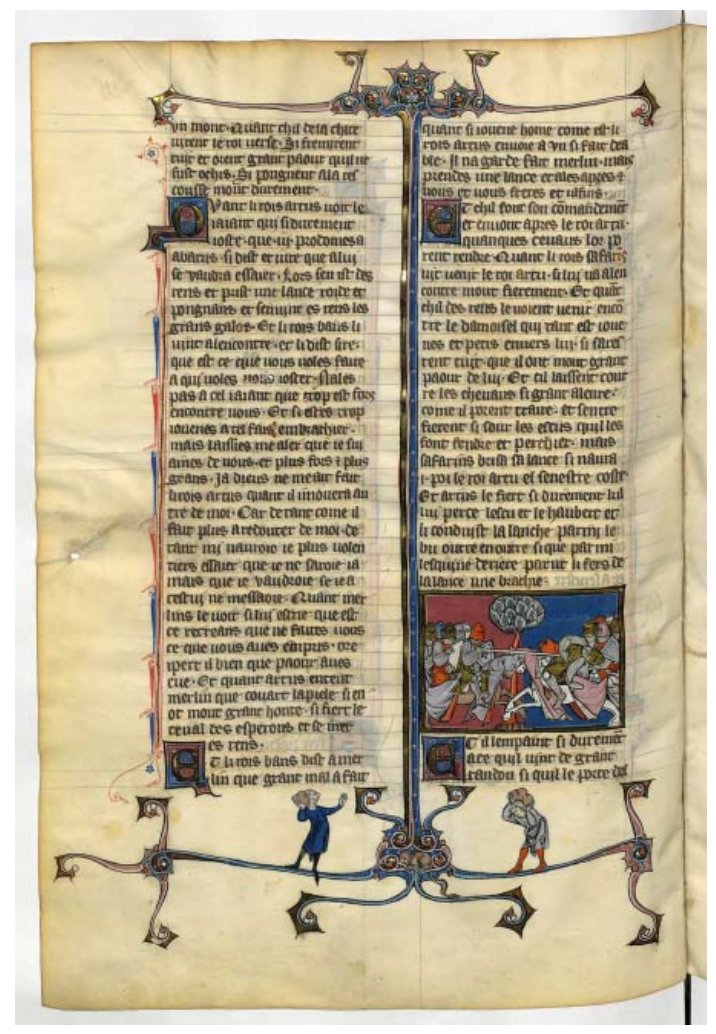

Figure 4: Paris, BNF, ms. fr. 95, f. 195v, Involute tendrils defining the space for the figural composition.

13 This does not mean, however, that much less figural "action" is present on the bottom border, only that it is constructed differently: not as central figural composition, but as action revolving around or on two sides of the central intertwinement. I will deal with this in my iconographical article about this manuscript. 
As in the top border, involute tendrils are quite frequent in the bottom border as well; normally they come in two pairs (as on the just mentioned f. 159v): one extends vertically or horizontally above the bottom border, and the other below. When one or both pairs are horizontally placed, it seems that the breadth they embrace defines the space allotted to the figural scene on the lower border: on f. 195v (Figure 4), for example, a terrified lion cub is hiding in the rhomboid-shaped intertwinement in the centre; diagonal involute tendrils on top "protect" it from two young men bearing a stone, coming from each side: the left one is prepared to throw, the right one still has the stone on his shoulders; the horizontal tendrils below the border extend to a point where (above their involutes) two men stand.

\section{Conclusion}

In this paper I have focused on pointing to some elements that reveal the artist's (or the planner's) careful consideration of the role that borders play in the overall appearance of a manuscript page in BNF, fr. 95, and thus show his or her personal involvement with it. This involvement was not only on the level of manu propria, at least if we consider this only as a "technical" determiner designating physical execution of the borders, but also on the level of mente propria, if we understand this as incorporating contemplation about how a page should look. Of course, it is not possible to claim that all elements mentioned are an expression of an individual's contemplation: for example, the basic difference between two border types, which was dependent on the position of the miniature in the text, was very likely a matter of established practice. Some pages show careful planning, and this probably has iconographical implications as well; further investigation will therefore be required on the importance of eye contact between figures and its possible relevance for understanding the marginal "story". Other pages seem to bear witness to the illuminator's stylistic, not iconographical differentiation between scenes which are generally similar enough; the use of gold background in some central clusters and the lack of it in others cannot really be interpreted iconographically, but it does point to a "belief" that even slight differences between the scenes should be artistically conveyed: close physical contact between two bodies is underlined by a common background, and a momentary contact of weapons of two fighting individuals deserves nothing of the sort. These instances are perhaps the most genuine testimonies of mente propria; it is my belief that it is necessary to remain very careful in suggesting how much was left to the individual artist's decision in compositions which appear to be highly customized, e.g. the ones directly above or below the miniature, which can, as shown, be regarded as conforming to a pattern that was followed without exception. On the other hand, such patterns, as well as 
those concerning the customized use of terminals on folios with borders of type B, confirm that there was careful planning and they are in that way revealing - if not in terms of the executing illuminator's mente propria, then very likely of the planner's.

\section{Bibliography}

\section{Source}

Estoire del saint Graal, Merlin, Suite vulgate, Le Roman des sept, sages, Pénitence Adam, Paris, Bibliothèque nationale de France, ms. fr. 95, http://gallica.bnf.fr/ark:/12148/ btv1b6000108b.

\section{Literature}

Loomis, R. S., Loomis, L. H., Arthurian Legends in Medieval Art, New York 1938.

McRae, J. E., Nelles, W., Text and Context: The Production of Images in Yale MS 229, La Mort le roiArtus. Essays on the Lancelot of Yale 229 (ed. Willingham, E. M.) pp. 29-38, Turnhout 2007.

Moore Hunt, E., Illuminating the Borders of Northern French and Flemish Manuscripts, 1270-1310, New York, London 2007.

Randall, L. M. C., Images in the Margins of Gothic Manuscripts, Berkeley 1966.

Stones, A., The Illustrations of French Prose Lancelot in Belgium, Flanders and Paris, 1250-1340, Ph.D. Dissertation, University of London (typewritten) 1970-1971.

Stones, A., The Illustration of BN, fr. 95 and Yale 229: Prolegomena to a Comparative Analysis, Word and Image in Arthurian Literature, (Busby, K.), pp. 203-260, New York, London 1996.

Stones, A., "Mise en page" in the French Lancelot-Grail: the First Hundred and Fifty Years of the Illustrative Tradition, A Companion to the Lancelot-Grail Cycle, (ed. Dover, C. R.), pp. 125-144, Woodbridge, Rochester 2003.

Stones, A., Gothic Manuscripts: c. 1260-1320. Part 1. A Survey of Manuscripts Illuminated in France, a - Volume 1, b - Volume 2, Turnhout 2013. 


\title{
Strukture bordur v arturjanskem rokopisu BNF, fr. 95 kot izraz umetnikove mente propria
}

\begin{abstract}
Ključne besede: knjižno slikarstvo, marginalije, bordure, cikel Lancelot-Graal
Prispevek analizira slogovne in kompozicijske poteze bordur (robov, ki "uokvirjajo « besedilo) v rokopisu, ki vsebuje dve obsežni romanci iz cikla LancelotGraal (Estoire del saint Graal, Merlin skupaj s Suite Vulgate) in dve nearturjanski besedili (Le Roman des sept sages, Pénitence Adam). Ločevati je mogoče dva osnovna tipa bordur, tu poimenovana tip A in tip B, ki se pojavljata glede na mesto miniature na strani: kjer je miniatura v levem stolpcu, je uporabljen tip A, kjer v desnem, tip B. Za tip A je značilno, da besedilo objame s treh strani: vertikalna bordura teče vzdolž levega stolpca, horizontalna pa po širini obeh besedilnih stolpcev. Pri tipu B se vertikalna linija spušča vzdolž desne strani desnega stolpca, torej teče med obema stolpcema, čeprav pomaknjena bliže desnega; spodaj in zgoraj se iz sredine na obe strani razraščata horizontalni borduri. Kot vezni elementi med vertikalno in horizontalnima bordurama so pogosto uporabljene figuralne kompozicije, ki so izvedene na nekaj tipičnih načinov, $\mathrm{v}$ razpravi ponazorjenih s primeri. Nekatere kompozicije, kot npr. dve nasproti dirjajoči figuri neposredno nad (pod) miniaturo, kadar je ta postavljena na vrh (na dno) stolpca, razkrivajo vzorec, upoštevan brez izjeme, in zato dopuščajo domnevo o dejavni vlogi glavnega iluminatorja oz. načrtovalca celostne podobe rokopisa, kar pa terja nadaljnje raziskave, ki bodo obravnavale širši severozahodno francoski rokopisni korpus s konca 13. in začetka 14. stoletja. Podrobnosti, kot je ohranjeno zlato ozadje $\mathrm{v}$ primerih, ko se dve figuri stakneta s telesi, in njegova odsotnost, kadar dotika med njima ni oz. je le dotik orožja, pa utegnejo pričati o osebnem "posegu« slikarja, ki je s to slogovno potezo izrazil mente propria.
\end{abstract}


Miha Zor

\title{
Border Structures in Arthurian Manuscript BNF, fr. 95 as an Expression of the Artist's mente propria
}

\author{
Keywords: manuscript painting, marginalia, borders, Lancelot-Graal Cycle
}

The paper analyses the stylistic and compositional characteristics of borders in a manuscript consisting of the first two romances of the Lancelot-Graal Cycle (Estoire del saint Graal, Merlin with Suite Vulgate) and two non-Arthurian texts (Le Roman de sept sages, Pénitence Adam). Two different types of borders are present, and in the article they are named type A and type B. They were employed with regard to the position of the miniature in the page: where the miniature appears in the left column, type A was used, and where it appears in the right column, type B was employed. The borders of type A embrace the text from three sides: the vertical border runs along the left column, and both horizontal ones spread over the space of both textual columns. In the case of type $\mathrm{B}$, the vertical border runs along the right side of the right column, that is between the two columns, but closer to the right one; on the top and bottom, horizontal borders spring from the centre to both sides (over both columns). Certain compositions make it possible to assume that the main illuminator or the planner of the overall appearance of the manuscript was actively present also as far as the borders are concerned. Other details - e.g. gold background when two figures form contact with their bodies, and the lack of such a background, when they do not touch or touch only with their weapons - may testify to a personal intervention of the practising artist, and this may be characterized as a stylistic trait revealing his mente propria. 